KIRJA-ARVIOITA

\title{
Itselliseksi oppijaksi ohjaajan tuella
}

\section{Lehtinen, Esko \& Jokinen, Tuija. 1996. Tutor - itsenäistyvän oppijan ohjaaja. Atena.}

Lehtisen ja Jokisen kirja liittyy jo pari vuotta sitten päättyneen AINO-projektin tuotantoon. AINO-projekti oli opetusministeriön rahoittaman avoimen yliopisto-opetuksen ohjaus- ja neuvontajärjestelmän kehittämisprojekti, jossa Jyväskylän yliopiston vastuulla oli tutortoiminnan kehittäminen ja oppimateriaalin tuottaminen tutorin tehtäviin kouluttautuville. Jyväskylän yliopistossa on pitkään järjestetty tutorkoulutusta ja toteutettu tutorointia avoimen yliopisto-opiskelun tukena, joten oli luontevaa, että ensimmäinen suomenkielinen tutorointiopas kirjoitettiin juuri siellä. Kuten Jukka Koro toteaa esipuheessaan, "tätä teosta on todella odotettu" ja niin lukijan odotuksetkin ovat korkealla kirjaan tarttuessaan.

Kirjan nimi on perusteltu. Tutor -nimitys on vihdoin vakiintumassa suomalaiseen kielenkäyttöön, kun parempaa kotimaista vastinetta ei ole lanseerattu. Lehtisen jossain aikaisemmassa yhteydessä ehdottama "opintoluotsi" voisi olla kuvaava, mutta tuntuisi aika keinotekoiselta. Tutorin merkitys englanninkielisessä yliopistomaailmassa on tosin hiukan toinen kuin Suomessa, mutta sanana se taipuu helposti suomen kieleen. Itsenäistyvä oppija viittaa prosessiin, jossa oppijat ovat matkalla kohti itsenäisyyttä ohjaajan tukemina.

Parasta kirjassa on selkeys ja helppolukuisuus sekä Lehtisen tekstistä välittyvä vankka kokemus ja henkilökohtainen ote tutorointiin. Runsaat esimerkit ja pohdintatehtävät aktivoivat lukijaa ja ovat käyttökelpoisia oman opettajuuden muuttamisprosessissa. Uuden alueen käsitteiden selventämisessä kirja täyttää odotukset hyvin. Laaja kirjallisuusluettelo on koottu kirjassa mainittuja viittauksia laajemmaksi, mikä palvelee teemoista syvemmin kiinnostuvia lukijoita.

Lehtinen lähtee liikkeelle käynnissä olevasta oppimisen ja koulutuksen murroksesta. Elinikäisen oppimisen teemavuosi 1996 onkin sopiva julkaisuajankohta tutorointikirjalle. Lehtinen käsittelee alussa andragogista lähestymistapaa aikuisten oppimiseen amerikkalaisten klassikkojen (M. Knowles, A. Rogers, C. Rogers) pohjalta. Humanistinen ihmiskäsitys on selvästi taustalla, mutta sitä ei sellaisenaan esitellä. Lehtinen lähestyy uutta ohjausstrategiaa vastakkainasettelusta perinteiseen luokkahuoneopetukseen suljetussa kontekstissa. Lehtinen ei halua tuomita opettamista täysin, vaan hän hakee laajempaa didaktista näkemystä, jossa tarvitaan sekä opettamista että ohjaamista. Viisaat aikuiskasvattajat ovat aina sekä opettaneet että ohjanneet" (s.50).

Urpo Harva kirjoitti jo vuonna 1955 teoksessaan Aikuiskasvatus, johdatus aikuiskasvatuksen teoriaan ja työmuotoihin Suomessa:

"Aikuinen ei tule kasvatuksen piiriin siitä syystä, että hän haluaisi saada itselleen valmiita mielipiteitä, vaan hän tulee siksi, että se, mikä hänellä on, ei tyydytä häntä. Hän etsii parempaa ja odottaa, että häntä etsinnässään tuetaan."

Tutoroinnin perusajatus on suomeksikin tullut kirjattua jo yli neljäkymmentä vuotta sitten!

Ohjaukseen liittyvien käsitteiden sekamelskaa Lehtinen selventää mind-mapilla sekä esimerkeillä tavallisimmista ohjauskäsitteistä anglosaksisessa kirjallisuudessa; avustaja, neuvonantaja, ohjaaja ja tutor saavat tarkemman luonnehdinnan. Lehtinen päätyykin esittämään tutorointia opettajan työn yläkäsitteeksi perustellen, että "tutor - sananmukaisesti "lempeä peräänkatsoja" - on kelpo nimitys sille oppimista avusta- 
valle ammattilaiselle, jota ennen kutsuttiin opettajaksi". Mahtaako Lehtisen käsitteellinen uudistus saada laajempaa kannatusta?

Tutorin muotokuvaa Lehtinen hahmottelee Grow'n klassisen SSDL-mallin (The Staged Self Directed Learning Model) kautta. Mallissahan oletetaan aikuisten kehittyvän riippuvasta oppijasta itseohjautuvaksi välivaiheinaan kiinnostunut ja sitoutunut oppija. Opettaja-ohjaajan rooli vaihtelee siten auktoriteetista delegoijaan ja muuttuu oppijan kehitysasteen mukaisesti. Lehtinen tuo esiin mallin puutteet, mutta pitää sitä kuitenkin merkittävänä yrityksenä jäsentää aikuisten opettamis- ja ohjauskysymystä, mitä se kieltämättä onkin.

Kirjan konkreettisin antitutorointia maistelevan aikuiskouluttajan kannalta on varmaankin "ohjaamisen huoneentauluksi" nimitetyt tiivistetyt ohjeet, joissa Lehtinen korostaa mm. ohjausfilosofian, aikuisoppijoiden ainutlaatuisuuden, oppimisilmapiirin, aitouden, visioinnin ja kannustamisen merkitystä. FFF-malli (fish, fishing and food) kuvaa hyvin ohjauksen kokonaistavoitetta: kalan antaminen akuuttiin nälkään tyydyttää vain hetkeksi, onkimisen opettaminen poistaa ongelman lyhyellä aikavälillä, mutta ruoan etsimisen ja valmistamisen opettaminen antaa evästä loppuiäksi.

Lehtinen haastaa koulutusorganisaatioita uudistumaan kokonaisvaltaisen ohjausjärjestelmän kautta. Lehtisen mukaan "kokonaisvaltainen ohjauksen suunnittelu ja toteutus ovat samalla osa koko organisaation kehittämistä", opettamisen uudistamisen pitäisikin kohdistua ohjauksen kehittämisen visiointiin. Tutoroinnin ulottaminen koko koulutusorganisaation kantavaksi ideaksi tuntuu kokeilemisen arvoiselta.

Kirjan keskeisissä luvuissa 4-9 ohjauksen kokonaisuutta lähestytään ns. oppimispolkumallin kautta. Mallissa ohjausta tarkastellaan viiden virstanpylvään kautta: 1. ennen kontaktiopetuksen aloittamista, 2. opintojen aloitusvaiheessa, 3. varsinaisen opiskeluprosessin aikana, 4. päättö- ja siirtymävaiheessa ja 5 . seurantavaiheessa. jokaiselle virstanpylväälle on omistettu oma lukunsa. Ensimmäisessä vaiheessa ohjauksella on merkitystä enimmäkseen oppilaitoksen markkinoinnin kannalta. Aloitusvaiheen ohjausta pohditaan opiskelijacasen kautta, jota kuljetetaan mukana seuraavissa ohjauksen vaiheissa. Portfolion esittäminen opiskelun aloittamiseen liittyvänä henkilökohtaisena kehittymissalkkuna tuntuu toimivalta.

Lehtinen ei esittele erilaisia ohjaustyylejä, vaan pitää ymmärtävää auttamista sopivana lähestymistapana kautta linjan. Oppijoiden yhteistyöhön liittyvät näkökohdat myös korostuvat. Tämä on sopusoinnussa Lehtisen ohjausideologian kanssa, mutta ohjaustyylien esille ottaminen olisi tuonut ehkä ensimmäistä kertaa tutorointiin tutustuvalle lukijalle viitteitä siitä, miten vaihtelevia ohjaustilanteet voivat olla ja miten tutor voi omalla käyttäytymisellään vaikuttaa tilanteen kehittymiseen.

Yksilöllisyyden huomioonottamista kuvaa oppimisen optimikokemuksia korostava motivaatioteoria (Csikszentmihalyi 1988). Tämän näkemyksen mukaan yksilön energiavirrat liikkeelle saava "flow-kokemus" (toimintatilaisuuden vaatimukset vastaavat yksilön taitoja ja valmiuksia suoriutua niistä) voi johtaa parhaimmillaan voimakkaaseen sisäiseen motivoitumiseen. Toistuvat flow-kokemukset ruokkivat itseään ja tuloksena voi olla itseohjautuvaa elinikäistä oppimista. Tutorin ammattitaitoa on tällaisen yksilöllisyyden tunnistaminen ja henkilökohtaisten opetussuunnitelmien laatiminen yhdessä opiskelijoiden kanssa.

\section{Mihin unohtuivat aikuisen avoimet oppimisympäristöt?}

Kirjan laajin luku Ohjaus opiskeluprosessin kuluessa on Tuija Jokisen kirjoittamana. Tekstin tyyli ei tässä oleellisesti muutu, vaan kirjoittajat ovat kyllä samoilla linjoilla. Jotakin kuitenkin muuttuu. Jokisen lähtökohtana on oppimisympäristö-ajattelu. Oppimisympäristö käsitetään laajasti oppijan toimintaympäristöksi, jossa on monia oppimislähteitä. Avoimissa oppimisympäristöissä oppiminen on joustavaa ajasta ja paikasta riippumatonta toimintaa. Etäopiskelun elementit ja niiden suunnittelu nousevatkin keskeisiksi Jokisen 
osuudessa. Oppimistehtävät, koulutusteknologia, etäohjauksen muodot, yksilöllistäminen, ryhmässä oppiminen, vertaistutorointi ja palautteen merkitys ovat käsittelyn kohteena.

Hetken lukija luuleekin jo pääsevänsä käsiksi tutorointiin avoimessa oppimisympäristössä; uuteen ulottuvuuteen ja uuteen tutorointivisioon. Pettymys onkin suuri, kun Jokisen mielenkiintoisen avoimiin oppimisympäristöihin orientoivan osuuden jälkeen Lehtisen kirjoittamat kolme viimeistä lukua liikkuvat muodollisen koulutuksen päättö- ja seurantavaiheen problematiikan pohdinnassa. Minne unohtuivat aikuisen avoimet oppimisympäristöt?

Kirjan metaforinen ohjauspolku kertoo sitoutumisesta organisoituun koulujärjestelmään; oppiminen on jotakin, joka alkaa ja päättyy instituution suojissa ja ohjauksella. Suljetun oppimisen malli näyttää sittenkin olevan vankasti taustalla. Sellaiset kysymykset kuin: miten tutor toimii todella avoimessa oppimisympäristössä tai pitääkö tutorointia ylipäänsä organisoida tai mitä olisi "avoin tutorointi" luonnollisessa oppimisympäristössä jäävat kokonaan ilman vastauksia ja visioita, kun niitä ei edes uskalleta esittää. Todisteena konservatiivisesta ohjausnäkemyksestä kirjan viimeisen luvun lopussa kirjoittaja toteaa, että "ohjaaminen ei olekaan hyppy tuntemattomaan, vaan mahdollisuus olla entistä aidommin itseensä luottava, osaava ammattilainen, jolle ohjattavat antavat auktoriteettiaseman". Tämä asettaa kertaheitolla kyseenalaiseksi kauniin ajatuksen tutorin tavoitteesta tehdä itsensä tarpeettomaksi. Eikö Lehtinen itsekään usko FFF-periaatteeseen?

Juuri "hyppy tuntemattomaan" voisi olla alku sellaiselle oppimiselle, jonka kautta oppija löytää elämäänsä uuden suunnan tai sisällön. Eikö tutorin pitäisi silloin olla myös valmis näihin hyppyihin oman roolinsa suhteen?

Todella uudenlaista ohjaajan muotokuvaa ei siis yritetäkään hahmotella tässä kirjassa. jostakin on kuitenkin aloitettava ja sillä tiellä tämä teos on hyvä avaus ohjauksen poluille, jotka toivottavasti johtavat enemminkin oppimisviidakkoon kuin valmiiksi viitoitetuille väylille. 